\title{
Paste Fills Technology in Condition of Estonian Oil Shale Mine
}

\author{
Juri-Rivaldo Pastarus, Julija Shommet, Ingo Valgma, Vivika Väizene, Veiko Karu \\ Tallinn University of Technology, Department of Mining, Estonia \\ juri-rivaldo.pastarus@ttu.ee,julia.shommet@hotmail.com,ingo.valgma@ttu.ee, \\ vivika.vaizene@ttu.ee,veiko.karu@ttu.ee
}

\begin{abstract}
Oil shale mining and processing industry in Estonia produce a wide assortment of waste could be considered as available fill materials. Waste rock which is not usable in civil engineering and road building may be used for backfilling underground mines. Paste fills technology, which has several benefits, requires careful selection of oil shale waste rock aggregates and other carbonate stones. The laboratory tests and theoretical investigations were made for determination the applicability of limestone and dolostone aggregates as backfill material. It enables to determine the feasible parameters of aggregates from oil shale mining waste rock. Analysis showed that limestone aggregates of Estonian oil shale mines suit best for backfill technology in conditions.
\end{abstract}

Keywords - oil shale industry, backfill technology, paste fill, fill materials, limestone and dolostone aggregate, geometrical parameters of aggregates.

\section{INTRODUCTION}

The oil shale industry of Estonia provides a significant contribution to the country's economy, but causes a large number of different problems [15][16]. Oil shale is used as a fuel for producing energy and shale oil [10][20]Error! Reference source not found.. The mining sector faces challenges to increase the output of mines and at the same time to minimize the environmental impact of mining [16]. Limestone and dolostone companies, where material is excavated by blasting and crushing technology, are in need of fillers distribution also.

Underground oil shale mining is performed by using a room-and-pillar method with blasting [11][16][17][18]. It is cheap, highly productive and easily mechanized. Unfortunately, if the depth of excavation is over $60 \mathrm{~m}$ (mine Estonia) the loss in pillars increases up to $40 \%$ [19]. On the other hand, there are problems of use or bury the waste in landfill due to large amount of neutral (limestone) and hazardous (ash) waste generated by oil shale industry Error! Reference source not found. Error! Reference source not found.. A complex approach is needed for solving the above mentioned problems. Backfill technology would have a significant impact on the mining practice in Estonian oil shale industry [8] [9][14][18]Error! Reference source not found.

Backfilling in mining operations is in wide use in all over the world. Nowadays attention has been focused on the use of combustion and mining byproducts as filling materials. Separation of limestone from the raw oil shale generates large amount of waste, which proportion is approximately $40 \%$.

Waste rock which is not usable in civil engineering and road building may be used for backfilling already mined areas Error! Reference source not found..

In modern backfill technologies paste fills are preferred [4]. It requires careful selection of fill materials, including limestone aggregates. Past fills method has several benefits, most of them are crucial for the usefulness of backfill technology. On the same time there is lack in data characterizing the above mentioned waste filling materials. The choice of a proper backfill material is essential in the control of fill costs and backfill properties after placement. The main aim of these investigations was to determine the applicability of waste rock aggregates as backfill material in condition of Estonian oil shale mines.

\section{Geological Situation}

The Estonian oil shale deposit is located in the north-eastern part of the country. The oil shale bed has a form of a flat bed slightly inclined $(2-3 \mathrm{~m}$ per $\mathrm{km})$ southward. The commercial oil shale bed and its immediate roof consist of oil shale and limestone seams Error! Reference source not found.Error! Reference source not found.. The main roof consists of carbonate rocks of varying thickness. Characteristics of the individual oil shale and limestone seams are rather different. The strength of the rocks increases southward. The underground mining works are going at deepness $35-65 \mathrm{~m}$, but at the southern border of deposit mining deepness will grow up to $120-130 \mathrm{~m}$, notable increases overburden and its pressure to pillars [8][11][16]. The thickness of commercial oil shale seam is about $2.8 \mathrm{~m}$. The waste rock separated from run of mine, which proportion is approximately $40 \%$, is suitable for production of construction and backfill material [13].

Limestone companies are mostly located in Harjumaa County. It is in the northwestern Estonia, on the southern shore of the Finnish Gulf, about $80 \mathrm{~km}$ to south from Helsinki, Finland. Geologically this area belongs to the southern slope of the Fennoscandian shield, where the Precambrian Early Proterozoic crystalline rocks of age $2.0-1.3 \mathrm{Ga}$ are covered by 
sequence of the Ediacaran and Paleozoic sedimentary rocks with age between 600Ma and 359Ma in Estonia [2]. In the Harjumaa County there are being registered 16 carbonate stone deposits, four of them: Vasalemma, Harku, Nabala, and Väo are listed as deposits of all-country importance [21].

\section{BACKFILL TECHNOLOGY}

In Estonian oil shale industry a wide assortment of fill materials is available [6][7]. The whole processing of oil shale from mining up to energy and oil generates large amount of different waste:

Separation of limestone from the raw oil shale generates large amounts of waste, which consists in $82 \ldots 94 \%$ of limestone and $6 \ldots 18 \%$ of oil shale residues. These are stockpiled in form of cones $(55 \mathrm{~m}$ height) and total area of these piles is about $3.5 \mathrm{~km} 2$. Limestone production is about $6.5 \mathrm{Mt}$ per year.

1. The Estonian Thermal Power Plants use two different oil shale combustion technologies: pulverized firing (PF) and circulating fluidized bed combustion (CFBC) technology. The compositional and morphological variation between $\mathrm{PF}$ and $\mathrm{CFBC}$ ashes [3] are principally controlled by firing temperature differences between combustion technologies, and by grain size difference of oil shale fuel. From the point of chemistry ash from oil shale combustion is very similar to cement (with exception in alkalinity) and there is no significant difference between the potential environmental impacts from the side of oil shale ash. About $4 \mathrm{~km} 2$ of the landfill are occupied with ash ponds. Annual production is about $5 \mathrm{Mt}$. The determination of different ashes parameters demands supplementary investigations and is under construction.

2. In modern backfill technologies paste fills are preferred [4][5]. It requires carefully selected grainsize distribution of solid particles and is able to flow without sedimentation in pipes by low water content $(10 \ldots 30 \%)$. In this case backfill slurry has several benefits:

Mixtures are able to set with lower or without presence of additional binders.

Shorter binding times and better mechanical properties.

Drainage and processing of bleed water eliminated.

Consequently, at a first approximation the limestone aggregates properties determine the behavior of backfill. Oil shale waste rock (limestone) is produced during extraction as reject material from separation plant and material from crushing and sizing operations in aggregate production. It became clear that production of aggregate produces large amount of non-commercial aggregate [13].

\section{GEOMETRICAL PARAMETERS OF AGGREGATES}

The porosity of fill material consists of the void spaces between solid fragments. If the fragments are solid spheres of equal diameters the cubic and rhombohedral pacing is possible (see Fig. 1) [1].
A

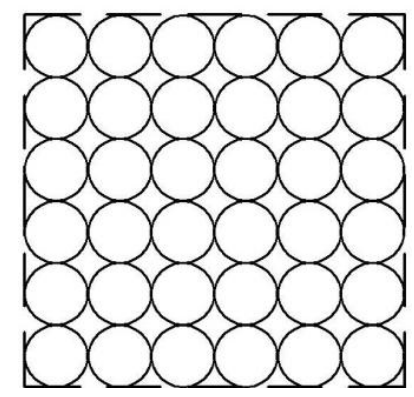

B

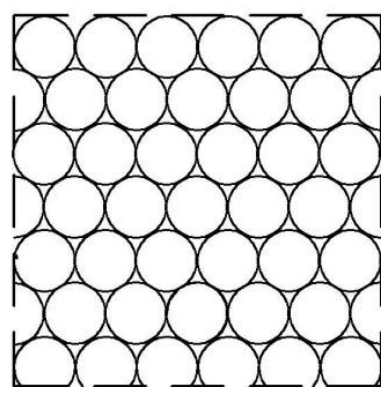

Fig. 1. Packing of the solid fragments [1], A - cubic packing; B rhombohedal packing

These two configurations represent the extremes of porosity for arrangements of equidimensional sphere with each sphere touching all neighboring spheres. The porosity of well-rounded backfill materials, which have been sorted so that they are all about the same size, is independent of the particle size and falls in the range of about $25.95 \%$ to $47.65 \%$, depending upon the packing [1]. If a backfill contains a mixture of grain sizes, the porosity will be lowered. In this case the smaller particles can fill the void spaces between the larger ones. The wider the range of grain sizes, the lower the resulting porosity.

In addition to grain-size sorting, the porosity of material is affected by the shape of the grains [1]. Well-rounded grains may be almost perfect spheres, but many grains are very irregular. Sphere-shaped grains will pack more tightly and have less porosity than particles of other shapes. The orientation of the particles, if they are not spheres, also influence porosity.

This phenomenon determines the bearing capacity of backfill/pillar. Conformation of getting theoretical result demands supplementary investigations of in situ conditions.

\section{A. Uniformity Coefficient}

The uniformity coefficient of a material is a measure of how well or poorly sorted it is. It is presented by following formula[1]:

$$
C_{u}=d_{60} / d_{10}
$$

where $C_{u}$ - uniformity coefficient; $d_{60}$ - grain size that is $60 \%$ finer by weight; $d_{10}-$ the grain size that is $10 \%$ finer by weight.

A sample with a uniformity coefficient less than 4 is well sorted, if it is more than 6 it is poorly sorted [1].

The grain-size distribution curve and uniformity coefficients for aggregate sizes 4/16, 16/32 and 32/63 $\mathrm{mm}$ have been determined. Fig. 2 demonstrates the 
grain-size distribution curve for aggregate size 16/32 mm, mine Estonia.

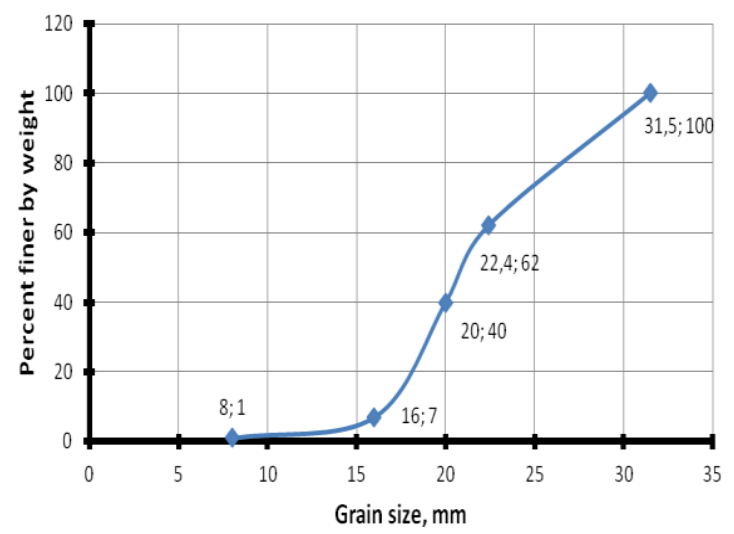

Fig. 2. Grain-size distribution curve. Aggregate size $16 / 32 \mathrm{~mm}$ mine Estonia

Investigation showed that uniformity coefficient for all aggregate sizes is less than 4. For limestone and dolostone uniformity coefficient is less than 3 . Consequently, the above mentioned aggregates are well sorted and they satisfy the paste fills requirement.

\section{B. Shape of the Coarse Aggregate}

Flakiness Index is the percentage by weight of particles in it, whose least dimension is less than 0.6 of its mean dimension. Flaky particles may have adverse effect on concrete mix. For instance, flaky particles tend to lower the workability of concrete mix which may impair the long-term durability. The results of flakiness index investigation in Estonian oil shale mines and open casts are presented in Table 1.

TABLE 1

FLAKINESS INDEX OF WASTE ROCK AGGREGATE

\begin{tabular}{lllll}
\hline & \multicolumn{4}{l}{ Flakiness index Fl (average), $\%$} \\
\cline { 2 - 5 } $\begin{array}{l}\text { Aggregate size, } \\
\text { mm }\end{array}$ & $\begin{array}{l}\text { Mine } \\
\text { Estonia }\end{array}$ & $\begin{array}{l}\text { Open cast } \\
\text { Aidu }\end{array}$ & $\begin{array}{l}\text { Tondi-Väo } \\
\text { limestone } \\
\text { deposit }\end{array}$ & $\begin{array}{l}\text { Kareda } \\
\text { dolostone } \\
\text { deposit }\end{array}$ \\
\hline $4 / 16$ & 9 & 6 & 11 & $5^{*}$ \\
$16 / 32$ & 6 & 3 & 7 & 4 \\
$32 / 63$ & 4 & 2 & 10 & 10 \\
\hline
\end{tabular}

*produced and tested aggregate $8 / 16 \mathrm{~mm}$

Investigation showed that the flakiness index depends on aggregate size for limestone aggregates of Estonian oil shale mines. If the aggregate size increases, the flakiness index decreases. In general, the flakiness index of produced aggregates does not exceed $35 \%$ and that depends on type of crushers and number of crushing stages [12]. If the flakiness index is less than $50 \%$ the negative influence on the strength parameters of backfill is negligible.

\section{AGgREgATE PARAMETERS FOR BACKFILLING}

A complex method, including laboratory tests and theoretical investigations, were made for determination of the applicability of limestone aggregates as backfill material. The results of investigations are presented in Table 2.

TABLE 2

OIL SHALE WASTE ROCK (AGGREGATES) PARAMETERS

\begin{tabular}{lll}
\hline Parameter & $\begin{array}{l}\text { Measured } \\
\text { values }\end{array}$ & $\begin{array}{l}\text { Recommended } \\
\text { values }\end{array}$ \\
\hline Porosity of fill material, \% & $40-50$ & $26-48$ \\
Uniformity coefficient & $1-2$ & $<4$, well sorted \\
Flakiness index, \% & $2-11$ & $<35$ \\
\hline
\end{tabular}

In conclusion, it is visible that the aggregates from oil shale mining waste rock can be used as a material for backfilling the underground mined area. As long as Estonian oil shale mines are located near to the backfill required areas, other aggregates of limestone and dolostone not suitable because of the location.

\section{RESULTS}

In Estonian oil shale industry a wide assortment of fill materials is available. In modern backfill technologies paste fills are preferred. It required careful selection of limestone aggregates as a component part in fill mixture and is able to flow without sedimentation in pipes by low water content. The general parameters for paste fills technology are porosity, uniformity coefficient and shape of coarse aggregate. Getting results based on large amount of theoretical investigations and of in situ experiments.

Porosity of fill material determines the amount of power plant ash in mixture. Theoretically it is between 26 and $48 \%$ depending on packing of the solid fragments. In real conditions, the fill material contains a mixture of different grain sizes and shapes. Investigation of in situ conditions showed that it is in range of $40-50 \%$, which guarantees optimum amount of ash in mixture.

Strength parameters of backfill are determined by uniformity coefficient of aggregates. It is calculated, using grain-size distribution curve. Investigation showed that uniformity coefficient is less than 4 . Consequently, all the aggregates are well sorted.

Shape of coarse aggregate influences on long term durability of mixture and it is presented by flakiness index. Laboratory tests showed that flakiness index for all aggregate sizes is up to 11 . If the flakiness index is less than $35 \%$, the negative influence on the strength parameters of backfill is negligible.

Analysis showed that limestone aggregates suit best for backfill technology in conditions of Estonian oil shale mines. Usable investigation methods and getting results are applicable for different aggregates as a component part in fill mixture.

\section{ACKNOWLEDGEMENTS}

Estonian Science Foundation grants No. 8123 (2010-2013) "Backfill and waste management in Estonian oil shale industry" - mi.ttu.ee/ETF8123, SA Archimedes project No. 3.2.0501.11-0025 (2012 - 
2015) "Sustainable and environmentally acceptable oil shale mining" - mi.ttu.ee/etp, SA Archimedes project No. 3.2.0501.10-0002 (2011-2014) "Basics of new utilization process for oil shale combustion solid waste" and Doctoral School of Energy and Geotechnology II, DAR8130/1.2.0401.09-0082 mi.ttu.ee/doktorikool supported the research.

\section{REFERENCES}

[1] C W. Fetter, Applied Hydrogeology. Third Edition. New York, 1994, Torino.

[2] H. Koppelmaa, J. Kivisilla, Geological map of the crystalline basement of North-Eastern Estonia, scale 1:200 000. Explanation to the map. 1997, Geol. Survey of Estonia. 37 pp.

[3] R. Kuusik, M. Uibu, K. Kirsimäe, Characterization of oil shale formed at industrial-seal CFBC boilers. Oil Shale, 2005, Vol. 22, No. 4 Special, pp. 407-419.

[4] J. Palarski, Selection of a fill system for longwall in coal mines. 8th International Symposium on Mining with Backfill. Minefill 04, Beijing, September 2004, pp. 82-96.

[5] J. Palarski, Polish experience: Best practices in Poland underground waste utilization. EU legislation as it affects mining. Infra 22944 TAIEX, Workshop, 30th November 2nd December 2006, Tallinn, pp. 75-85.

[6] J.-R. Pastarus, Improved underground mining design method for Estonian oil shale deposit. 5-th International Scientific and Practical Conference on Environment, Technology and Resources. Latvia, Rezekne, June 16-18, 2005, pp. 270-274.

[7] J.-R. Pastarus, Sabanov, S. Backfilling in Estonian oil shale mines. In: Proceedings of teh 3rd International Conference AMIREG 2009: Towards sustainable development: Assessing the footprint of resource utilization and hazardous waste management, Athenes, Greece, 2009. (Eds.) Z. Agioutantis, K. Komnitsas. Athens, Greece: 2009, 344 - 347.

[8] J.-R. Pastarus, M. Lohk, Waste management in Estonian oil shale industry. In: Sustainable Developement in the Mineral Industry: Aachen International Mining Sumposia, Fifth International Conference, RWTH Aachen University, 14 17 June 2011. (Ed.) P. HN. Martens, T. Katz. Essen: VGE Verlag GmbH, Essen, 213 - 218

[9] E. Reinsalu, I. Valgma, Geotechnical processes in closed oil shale mines. Oil Shale 2003, 20(3), 398 - 403.

[10] E. Reinsalu, I. Valgma, Oil Shale Resources for Oil Production. Oil Shale 2007, 24, 9 - 14.

[11] S. Sabanov, T. Tohver, E. Väli, O. Nikitin, J.-R. Pastarus, Geological aspects of risk management in oil shale mining. Oil shale 2008, Vol. 25, No. 2 Special, pp. 145-152.

[12] T. Tohver, Utilization of waste rock from oil shale mining. Oil Shale 2010, 27(4), 321 - 330.

[13] T. Tohver, Utilization of waste rock from oil shale mining. Tallinn University of Technology. Thesis on Power, Electrical and Mining Engineering D48. TTU Press, 2011, Tallinn, $123 \mathrm{pp}$.
[14] V. Väizene, Backfilling technologies for oil shale mines. Valgma, I. (Eds.). Resource Reproducing, Low-wasted and Environmentally Protecting Technologies of Development of the Earth Interior $(1 \mathrm{pp}$.$) . Tallinn: Department of Mining$ TUT; 2009, Russian University of People Friendship

[15] I. Valgma, Oil Shale mining-related research in Estonia. Oil Shale 2009, 26(4), 445 - 150.

[16] I. Valgma, A. Västrik, V. Karu, A. Anepaio, V. Väizene, A. Adamson, Future of oil shale mining technology. Oil Shale, 2008, 25(2S), 125 - 134.

[17] I. Valgma, T. Tammeoja, A. Anepaio, V. Karu and A. Västrik, Underground mining challenges for Estonian oil shale deposit. Buhrow, Chr.; Zuchowski, J.; Haack, A. (Eds.). 2008, Schacht, Strecke und Tunnel. Freiberg, TU Bergakademie, pp. 161-172.

[18] I. Valgma, T. Kattel, Low depth mining in Estonian oil shale deposit-Abbau von Ölschiefer in Estland. In: Kolloquium Schacht, Strecke und Tunnel $2005: 14$. und 15. April 2005, Freiberg/Sachsen: Kolloquium Schacht, Strecke und Tunnel 2005 : 14. und 15. April 2005, Freiberg/Sachsen. Freiberg: TU Bergakademie, 2005, 213 - 223.

[19] I. Valgma, E. Reinsalu, S. Sabanov, V. Karu, Quality control of Oil Shale production in Estonian mines. Oil Shale 2010, 27(3), 239 - 249

[20] E. Väli, I. Valgma, E. Reinsalu, Usage of Estonian oil shale. Oil Shale 2008, 25(2S), $101-114$.

[21] A. Notton, U. Sõstra, The geological perspectives for Paleozoic carbonate raw material mining in Harjumaa County, Estonia. Lahtmets, R. (Eds.). 9th International Symposium Pärnu 2010 "Topical Problems in the Field of Electrical and Power Engineering" and "Doctoral School of Energy and Geotechnology II", Pärnu, Estonia, June 14 - 19, 2010 (53 - 58). Tallinn: Estonian Society of Moritz Hermann Jacobi

[22] Karu, V. (2011). European Union Baltic Sea region project "MIN-NOVATION". Oil Shale, 28(3), 464 - 465.

[23] Karu, V.; Valgma, I.; Rahe, T. (2013). Mining Waste Reduction Methods. Zakis, J. (Toim.). 13th International Symposium "Topical Problems in the Field of Electrical and Power Engineering", Doctoral Scholl of Energy and Geotechnology II, Pärnu, Estonia, 14-19.01.2013 (278 - 280). Tallinn: Elektrijam

[24] Karu, V.; Västrik, A.; Valgma, I. (2008). Application of modelling tools in Estonian oil shale mining area . Oil Shale, 25(2S), $134-144$.

[25] Koitmets, K.; Reinsalu, E.; Valgma, I (2003). Precision of oil shale energy rating and oil shale resources. Oil Shale, 20(1), $15-24$.

[26] Valgma, I (2003). Estonian oil shale resources calculated by GIS method. Oil Shale, 20(3), 404 - 411.

[27] Valgma, I. (2009). Oil Shale mining-related research in Estonia. Oil Shale, 26(4), 445 - 150.

[28] Valgma, I.; Leiaru, M.; Karu, V.; Iskül, R. (2012). Sustainable mining conditions in Estonia. 11th International Symposium "Topical Problems in the Field of Electrical and Power Engineering", Doctoral Scholl of Energy and Geotechnology, Pärnu, Estonia, 16-21.01.2012 (229 - 238). Tallinn: Elektriajam. 